\title{
Cultural, Communicative and Relevance Factors as the Bases for Decision Making in Translation
}

\author{
Olga V. Petrova* \\ Linguistics University of Nizhny Novgorod \\ 31a Minin Str., Nizhny Novgorod, 603155, Russia
}

Received 31.07.2018, received in revised form 05.09.2018, accepted 11.09.2018

\begin{abstract}
The aim of the article is to show the role of translator's cultural awareness, ability to be guided by communicative factors and to assess relevance of information in decision-making. The author's analysis of possible choices and decisions is based on understanding translation as a creative process of interlanguage and intercultural mediation presupposing the translator's ability to asses and take into account a wide range of parameters that cannot be formalized, such as background information, the speaker's intention and relevance of information.

The research has shown that the main difference between a human translator and a translating machine, as well as the main advantage of the former over the latter is the ability of a person to make nonprogrammable decisions. Unlike a machine, a person can assess relevance of information; relate words to their context and not only to the subject domain; reveal implications and allusions; identify culturally sensitive elements of the text. The success of contextually and culturally correct decisions depends on the translator's professional mentality, the development of which must become the number one priority in training translation students.
\end{abstract}

Keywords: relevance, context, cultural awareness, choice, decision, translator's professional mentality.

Research area: culturology.

Citation: Petrova, O.V. (2018). Cultural, communicative and relevance factors as the bases for decision making in translation. J. Sib. Fed. Univ. Humanit. soc. sci., 11(9), 1453-1466. DOI: 10.17516/1997-1370-0315.

\section{Introduction}

These days they speak a lot about the approaching era of computer translation. Some young translators are scared. When they see headlines like "Kissing Language Barriers Goodbye" or "A Computer Can Now Translate Languages as Well as a

(C) Siberian Federal University. All rights reserved

* Corresponding author E-mail address: o.v.petrova.nn@gmail.com

This work is licensed under a Creative Commons Attribution-NonCommercial 4.0 International License (CC BY-NC 4.0). 
Human!" they sincerely believe that very soon they will be ousted by Google Translate, Ili, Pilot, Travis the Translator, iTranslate Voice, SayHi, WayGo, TripLingo, Papago or some such device or application - their name is legion. When you say half in joke that they probably will, but only if they translate as poorly as Google does, for in this case Google will outperform them in terms of time and volume, they are not much reassured. Time and volume are tangible, quality is not. However, even now, with the appearance of Neural Machine Translation System, time and volume remain the only advantages of machines over human translators.

Translation is a complex process. Over 40 years ago Marilyn Gaddis Rose wrote: "Put as plainly as possible, translation is problem solving" (Gaddis Rose, 1979: 20). Solving a problem in translation amounts to making choices and decisions. Today there is vast literature on what kinds of choices translators have to make and what influences (or rather should influence) their decisions. Authors discuss it in the context of the psychological decision-making theory (e.g. Prassl, 2010), in cultural and linguistic aspects. For Katharina Reiss solving a problem is based primarily on the type, kind and individuality of the text (Reiss, 1981), for Jeremy Munday the key factor is evaluation, i.e. a translator's subjective stance (Munday, 2012). Wolfram Wilss describes decisionmaking behaviour in terms of "an interaction between the translator's cognitive system; his linguistic, referential, sociocultural and situational knowledge bases; the task specification; and the texttype-specific problem space" (Wilss, 1994: 131). Among the most important aspects of the text they name culture specificity and genre conventions (Prassl, 2010). The majority of authors emphasize the role of cultural decisions.

Apart from papers explicitly discussing the process of making decisions in translation, there are many recent researches on those aspects of translation that form the foundation of decision making. They are cognitive (Braun, 2016; Kushnina, Krivoruchko, Ushakova, 2016; Remkhe, Nefyodova, 2016), cultural (Buden et al., 2009), creative (Massardier-Kenney, 2010) and even interdisciplinary (Dizdar, 2009) aspects. All these aspects show both the nature of problems that a translator has to solve and the character of choices they can make.

On the surface, it seems that machines must be much better at making choices. They can quickly process an incredible number of factors, correlate them and incorporate the results into their final decision. And yet, with all the temporal and quantitative superiority of computers, there are choices and decisions that can be adequately made by human translators only. What is it that the best machine is not able to do (at least now) while an average (!) human translator is? 


\section{Communicative situation. Sense. Relevance}

Translation usually starts with the so-called pre-translation text analysis. It means answering a lot of questions about the text itself and about the situation in which it was written, finding information about the author of the text, the time when it was written, the purpose for which it was written, the theme, the target audience, the genre of the text, its composition, and style. Then comes another group of questions concerning the communicative situation of translation: the purpose of translation, its target audience, the degree of cultural similarity between the SL and TL recipients, their awareness of the things described in the text, etc. Comprehensive models of text analysis include double figures of parameters, both linguistic and extra linguistic. A good example is the model suggested by Christiane Nord (1991), who names 8 external and 8 internal factors to be taken into consideration by a translator. Let us be guided by her pattern of analysis (omitting some factors that are not relevant for the purposes of this paper) and see how it works.

1. First of all it is necessary to identify the author of the text (or sender, in Ch. Nord's terminology). Why? How does it help? What should we learn about the author? There can be no universal answer. It all depends on the character of the text. With literary texts it implies volumes of information. An author's individual style is predetermined by such factors as time and place they live in, a literary school or trend they belong to, their personal inclinations and preferences, etc. With journalists it is also essential to know their political views, probably even their party affiliation. With technical writers all this is irrelevant, but it is important to ascertain if the writer is a native speaker of the language in which the text is written. Since decision making is actually different with different types of text, even at this stage it is necessary to make decisions about the relevance of information. What is relevant for fiction may not be relevant for technical texts. Among other things, the translator's relevance judgment will influence the character and extent of information search.

Suppose there is a supersophisticated computer program that is able to identify the genre of the text (or just allows input of this information before the process of translation starts) and can match it with a list of facts that should be established about any author of a text belonging to this particular genre. It still won't be able to decide what is relevant in this particular case. Which facts of the author's biography can give a clue to the way a particular word should be translated? How important is it to know that Oscar Wilde was a leader of Aestheticism in his time? Very important. In many cases it will be crucial for choosing a proper TL word in translation. Is it equally important 
to know that he was Irish? Hardly so. And James Joyce? It is vital. How do translators know what is important and what is not? Before analyzing the text they have already read it, so now they can look through the information about the author and choose only what is relevant for translating it. How can a computer know it? A rhetorical question. Making decisions about relevance cannot be algorithmised. It requires evaluation, a translator's personal judgment.

2. The author's purpose (or intention). Something impossible for a machine to identify. There are cases when the purpose is predetermined by the genre. A guide, an instruction, a manual have a clear-cut purpose of telling people how to do something. But a newspaper article can be written for various purposes: to inform, to persuade, to instigate, to reassure, etc. A translator knows it after reading the text, learns it from the content, from the general tone of the text. A computer can easily identify the field, the topic, probably even the genre. But there are no elements of composition and style that could be taken as unambiguous signs of the author's intention. Is the intention relevant? Of course it is, since rendering it requires the choice of means used for the same purposes in the TL. Can a computer see it? Hardly.

3. The target audience (recipient) of the original and the intended target audience of translation. What should we know about them? It again depends on the text. We should know whether the text is intended for the general public or for a particular group (adults, children, professionals, women, etc). We should also know if the translation is is intended for a similar group in the target culture. Suppose a computer program provides for the input of this information before it starts translating. But even if we have made this choice for it, what will it do with this information? How can it compare the background knowledge of the SL and TL audiences, the way they perceive and evaluate the same facts? Human translators do it on the basis of their personal experience, their knowledge of the two cultures (one of which is their own).

4. The source from which the text comes (medium). It is mainly relevant for social and political journalism, since the journal that publishes the text may be a clue to the author's political beliefs, which is important for rendering the axiological aspects of the text in translation. Whether it is relevant in the case of a particular text is for the translator to decide. But how can a computer assess the character of a journal? And how can it decide whether it is relevant or not?

5. When and where the text was written (time and place). In many cases it is explicitly stated, but sometimes a translator has to deduce it from the text itself, which a machine cannot do. For a human translator the phrase "sputnik-panicked classrooms 
of America" can be a chronological marker, either known or easily findable: it refers to the large increase in funding for science teaching in American schools after the Soviet Union launched its first sputnik in 1957. So if it appears in the text as something contemporary with the rest of the story, the period is determined. For a computer the phrase has no chronological significance. The main thing, however, is that it is impossible for a computer to decide whether this information (the time) is relevant for translating this particular text or not.

So much for external factors characterizing the original text. We can see that even at this first stage of pre-translation analysis translators have to make many choices mainly based on their judgment, on their ability to assess the relevance of the external, extralinguistic information that should be found. A computer - if taught to do so - can only accumulate an indiscriminate mass of information and it will not be able to assess its relevance and to process it purposefully.

As for the parameters of the text itself (internal factors, according to Ch. Nord), they are even less accessible for a machine. Ch. Nord lists the following factors: subject matter, content, presuppositions - "implicitly assumed by the speaker, who takes it for granted that this will also be the case with the listener" (Nord, 1991: 95), - text composition, non-verbal signs, lexis, sentence structure, and suprasegmental features. It is evident that not all these parameters can be identified and analyzed by a machine. As for the subject matter, computers seem to be able to cope with it. Or at least with identifying the domain. If a text is properly prepared for machine translation there is no problem doing it. In the majority of cases it can be identified on the basis of ideoglossary. But the fact that lexically a text pertains, say, to the domain of cinema does not necessarily mean that it is about cinema. It will probably help the computer to find some corresponding words in the TL. Corpus statistical and neural techniques will even help to identify whole phrases and idioms. But all this will not help to render the real content. Why not, will be shown later.

Analysis of the content shows that in order to understand the meaning it is often necessary to find some additional information. The problem here is very much the same as it was with the information about the author. It is the matter of choice between "as much as possible" and "sufficient", "relevant" and "irrelevant". It is only the translator who can decide what kind of additional information is needed. Is it necessary to find details, say, of Charley Chaplin's private life if we translate a text about social aspects of his films? It depends on whether the author somehow alludes to it or not. Is it necessary to find facts concerning his conflict with the people "at the helm of society"? 
Again, it depends. Sometimes an innocently looking phrase can require it: if the author says that they exiled Chaplin the translator must know in what way it was done, just to find a correct verb in TL.

Presuppositions are obviously beyond the reach of computers, while they are sometimes essential for understanding the content.

Purely formal structural aspects of text composition (division into parts, chapters, paragraphs, etc.) are quite analyzable for a computer, but the way these components correlate, the very logic of composition is beyond it.

There are only two exceptions, non-verbal signs and sentence structure that a machine can analyze properly. As for non-verbal signs, there are no special decisions to make. But if a machine is taught to analyze sentence structure, the only decision it will be able to make is to reproduce it in translation. It will lead to syntactic calquing and will make the TL text unnatural and difficult to read, while for a trained human translator sentence structure is a sign of the author's style and communicative intention that will require a special attention in choosing corresponding (but not the same!) syntactic forms and figures in TL.

\section{Content. Context. Cultural awareness}

Analysis over, translation itself begins. Now all the answers obtained at the previous stage should be used as a basis for choices and decisions on how to translate. Let us see how it works and why human translators have advantages over machines.

Suppose we have to translate a text for a volume devoted to Chaplin, whose $130^{\text {th }}$ anniversary will be commemorated next year. The book is a collection of articles written over several decades and discussing various aspects of Chaplin's life and films. The text "Indomitable little man" was written by Joseph North and published in "The Worker" (July 12, 1964).

After reading the article we know that the bulk of it is a retelling of the most significant episodes of Chaplin's "Modern Times". At the same time, after the pretranslation analysis we know that Joseph North was not a film critic. He was a leftist political journalist. So we can assume that the article is not a film review. It is most probably devoted to some socio-political aspects of Chaplin's film. The more so because we see that in the first and in the last paragraphs (the so-called strong positions) the author uses variations of the same phrase about reaching for the gun at the mention of the word "culture". Let us see what else we have to know in order to make the right decisions and adequately translate the first paragraph: 
Only those who reach for their gun when they hear the word "culture" (like the late critic, Herr Dr. Joseph Göbbels) can dislike Charlie Chaplin whose works are enjoying a revival in New York today. I took the occasion in the current torrid spell to re-see his "Modern Times". I can only say that it remains a masterpiece of art, and a profound comment on contemporary life in these United States.

If we have not recognized the allusion, we'll wonder what this strange phrase is doing in the first sentence of a text that is presumably about Chaplin, and why the author mentions Joseph Göbbels. By the time the article was written Göbbels had been dead for nearly 20 years. Why bring him in? For a human translator it is a warning sign: if I don't understand what a word or a phrase is doing in the text, it means that I have missed something. There is some unrecognized implicit information. So the translator starts looking for it and easily finds both the phrase itself with its accepted Russian translations and the explanation of why it is associated with Göbbels. Now it is time for making decisions. Which of the existing translations to choose? It will depend on several things: their recognizability, length (since it is a part of a larger sentence, " $я$ хватаюсь за пистолет" is probably better than “я снимаю с предохранителя свой пистолет"), the necessity to paraphrase it again in the last sentence of the text, etc. How should the excessive styling "Herr Dr. Joseph Göbbels" be rendered in translation? Should we drop "Herr" or keep it? What is its stylistic function? How would it be better to translate "Herr": "г-н”, “господин” оr "герр"? Why? What could and should be done with the word "critic", which is hardly associated with Göbbels in the Russian mind and which is used again in the last sentence, but this time in inverted commas?

Which of these choices can a machine make? Or rather - do such problems exist for a machine? Certainly not. Google Translate offers the following Russian variant:

Только те, кто достигает своего пистолета, когда они сльишат слово «культура» (как в конце критик г-н д-р Джсозеф Геббельс) может не понравиться Чарли Чаплина, чьи работь пользуются возрождение в Нью-Йорке сегодня.

Certainly there are more powerful programs, with better grammar, that will not make so many mistakes. But none of them will make decisions on the basis of the considerations discussed above. 
Now comes the second sentence. What is "the current torrid spell"? Since the word "spell" does not belong to any domain the text can be associated with, a computer will make an arbitrary choice between different options: “заклинание”, “приступ”, “период”, “припадок”, “заговор”. Google Translate chose “жаркое заклинание”. A human translator will probably look at the date and think that it must have been very hot in New York on July 12, so it is rather a period of hot weather. But what is the connection between this torrid spell and the occasion to re-see the film? What do people do when it is too hot? They look for a cool place. If Chaplin's films were enjoying a revival it means that they were on in big cinema-theatres. At the time the article was written air-conditioning used to be an attractive feature of big cinemas. So it is clear that the author decided to combine the useful with the pleasant. Now for the translator all pieces fit together. But this is obviously a situation that requires pragmatic adaptation of the text in translation. Especially today when people can stay at home, in an air-conditioned room and see the movie using any electronic device they like. So there should be some explanation, some comments. Or should there? How relevant is it today that fifty-odd years ago it was very hot in New York on a particular day in July? Again it is a matter of choice. What is better: to add some information, thus overcharging the sentence, or to omit this irrelevant fact? The decision depends on the purpose of translation. If the text is being translated for the book commemorating Chaplin it might be reasonable to omit it. But if the same text were intended for a book about Joseph North, about his style, his journalistic manner, it would be necessary to find some compact way of preserving this phatic technique in translation.

Which of these choices can a computer make?

In the last sentence of the paragraph there is one more problem: "contemporary life in these United States". Contemporary with whom? With Chaplin or with the readers of the article? Chaplin's film was certainly a comment on the life in midthirties. But is it what the author means? Why "remains"? How could time change it? How could the film stop being a profound comment on the time captured in it? The answer is found in the word "these". Not those, not the United States of the thirties, but these, the United States of the sixties. Now the problem is purely lexical. What is good in English ("remains a comment on life in these United States") is somewhat strange in Russian - a thing created decades ago cannot "оставаться комментарием к жизни в сегодняшних Соединенных штатах", because it was not created as such. So it is necessary to apply some transformation - which a human translator 
can easily do, while Google Translate says “она остается шедевром искусства и глубокий комментарий о современной жизни в этих Соединенных Штатах”, whatever it might mean.

There is no need to go through the entire text to show that translators constantly find themselves at crossroads and intersections where it is necessary to make choices. Even though in the majority of cases it boils down to choosing a right word, the factors that should be taken into consideration are so complex and manifold that they can hardly be formalized. For example, if a character in the book says "We must be going" it is not enough to know what the person means. Sometimes it is also necessary to know how other characters understand it. The phrase itself can have at least two meanings: 1) it is time to go to some other place (not to be late) or 2) it is necessary to leave the place (say, because the speaker knows that it isn't safe to stay). In the first case it can be translated in several ways - “Нам надо идти”, “Нам пора идти”, etc. In the second case it will rather be something like "Пора уходить", "Нам бы лучше уже уйти", etc. But if the text describes a situation of misunderstanding, which becomes evident only some time later, it is better to avoid verbs like "идти" and "уходить". In this case it is necessary to create the same ambiguity that would later explain and justify the behavior of the character who misunderstood the phrase (e.g. "Нам пора"). Here the basis for our decision is not just vocabulary (something a computer can cope with), but the very composition of the text with a somewhat delayed explanation of the real meaning. Obviously not a choice for a machine to make!

Context-based choices can be illustrated with the translation of the title "Why are some scientists unhappy with the Nobel prizes?". Taken outside the context of the article (which is about the necessity to change the Nobel prize rules and regulations) it could be translated just as Google Translate does: "Почему некоторые ученые недовольны Нобелевской премией?" It is necessary to read the whole article to understand that it is not the Nobel prizes that the scientists are unhappy with, but the obsolete rules of nominating and selecting the laureates that no longer reflect the way modern science works. Unless we know it from the context we might believe that they are unhappy with the status of the prize or with the amount of prize money. This is the only way in which the translation "Почему некоторые ученые недовольны Нобелевской премией?" can be understood. It does not leave room for any other interpretation. So it is necessary to make the Russian version more explicit ("Почему некоторым ученым не нравятся правила присуждения Нобелевской премии?”, “Почему некоторым ученым не нравится, как присуждаются Нобелевские премии?”, etc.). 
As for culturally based choices, they are probably the least tangible. As Bilal Khalid Khalaf (2012) says, translators continually make decisions about cultural issues, and these decisions have less to do with finding the cultural inscriptions of a term than with reconstructing its values. And not only in sociocultural translation of which Bilal Khalid Khalaf writes in his article. A translator deals with culturally based choices much more often than people realize. The easiest thing is to make decisions about the way national phenomena and realia can be rendered in translation: Sergej Vlahov and Sider Florin(1986) have long ago described it all. Much more difficult is it to spot those things that seem to be the same in the two cultures but in fact are perceived quite differently. "Спекуляция" is a good example. In its denotation it coincides with the English "speculation". They both mean buying something at a lower price and selling it at a higher price thus making profit. However, the connotations are quite different - or at least they used to be. In the centralized economy of the Soviet Union “спекуляция” was considered an economic crime, while in the United States it is a risky, but quite legal activity. Americans could not understand the Soviet attitude and ascribed it to the tendency of the Soviet Government to forbid any profitable private business (Kabakchi, 2002). So the translator should think twice before translating "спекуляция" as "speculation" and vice versa. Not because they are "false friends". Technically they are not. But in many situations the translator's cultural awareness will suggest another decision (e.g. making a note or using words like profiteering, black marketeering, etc.).

Differences in the cultural background of SL and TL speakers can be illustrated with another example. In John Steinbeck's “The Winter of Our Discontent” (Steinbeck, 1996) there is an episode when the main character's son rushes into the kitchen through the back door and says that his father's boss is outside and wants to see him.

"Now what?" Mary demanded. "Well, ask him in." "I did. He wants to see you outside." "Ethan, what is it? You can't go out in your robe. It's Easter Sunday.” "Allen,” I said, "you tell Mr. Marullo I'm not dressed. Tell him he can come back later. But if he's in a hurry, he can come in the front door if he wants to see me alone."... Allen shot back. "He's going around front."... I went through the house and opened the front door. Marullo was on the porch... (Ch. 7).

There seems to be no problem translating it. There is a back door (задняя дверь, черный ход) and a front door (парадная дверь, парадный ход, главный вход), there 
is a porch (веранда, терраса, крыльцо, вход). The choices seem to be purely lexical. But the situation itself might puzzle a Russian reader. Why can't Ethan go outside in a dressing gown and slippers and see his boss at the back door, but at the same time it is quite all right for him to go to the front door? How is it that Marullo, who wants to see Ethan outside, is quite satisfied with going to the front door? Moreover, it is at the front door that Marullo can see Ethan alone. Dictionaries define "front door" as the main entrance giving direct access to street or road, which fully coincides with the definition of "парадная дверь". To understand it, it is necessary to know what a typical house in a small New England town looks like. It is necessary to know that a porch is not 'крыльцо' there. It is "веранда" or "терраса". And it is often screened, which means that talking on the porch is being neither inside the house nor in the street. The decision a translator should make is far from being lexical. It is necessary to make the whole situation understandable for the reader with a different cultural background.

These things cannot be formalized. A computer cannot have any cultural awareness, so it is not capable of identifying such a problem, let alone solving it. It does not mean that all human translators are. These days we see too many poor translations resulting from inability of human translators to see what choices they are faced with and what kind of decisions they are supposed to make. It is caused by several factors. One of them is the tendency to employ services of people who are not professional translators, i.e. of people who can speak a foreign language but haven't got special training as translators or interpreters. Their services are cheaper, just as using a machine is. In their mentality they do not differ from a machine either, but they cannot compete with it in processing speed and performance. With the development of machine translation this type of non-professionals is doomed.

However there are many professional translators who have problems identifying those intersections where a choice should be made. Sometimes it is a result of insufficient scope of knowledge. If such translators specialize in a particular subject field they quickly acquire the necessary fund of applied knowledge and can make correct decisions.

The situation becomes much more serious when a translator's machine-like mode of thinking results from the way they have been trained. In some schools professional training of translation students is limited to purely technological aspects of translating. Students are taught to use all kinds of techniques and transformations irrespective of whether they are needed in a particular text. They are not taught to analyze the text properly. Pre-translation analysis in such cases becomes a formal, autonomous 
procedure. They state facts about the situation in which the text was written, they look up some information about the subject matter and then they start substituting TL words and phrases for those of the SL. The only type of decisions they are trained to make is choosing a suitable TL word from among those listed in the appropriate dictionary entry. Translation students trained in this way have no chance against a computer. The main difference between a human translator and a machine is that a computer performs standard operations while people can think and make decisions based on their ability to analyze content, context and cultural meanings. This is what translation students should be taught to do.

\section{Conclusion}

Translation is a process that presupposes a lot of nonprogrammable decision making involving the translator's ability to assess relevance of information, to relate words to context, to reveal implications and allusions, to identify culturally sensitive elements of the text. A translator's judgment and intuition are subjective, so they are not necessarily correct. However this limitation can and should be overcome in the process of professional training by shifting the emphasis from developing technological skills to the formation of specific translator's mentality, a professional mode of thinking, by teaching students to correlate semantic text units with the communicative situation in which the original text was written, to reveal intratextual and intertextual relations of elements, to remember about cultural value of notions, and to perceive a text as an integral unit of translation. It is this professional mentality that gives any human translator a decisive advantage and superiority over the best computer.

\section{References}

Bilal, K.K. (2014). Why and how the Translator Constantly Makes Decisions about Cultural Meaning, In American Journal of Linguistics, 3 (1), 1-8. DOI:10.5923/j. linguistics.20140301.01

Braun, S. (2016). The importance of being relevant? A cognitive-pragmatic framework for conceptualising audiovisual translation, In Target: International journal of translation studies, 28 (2), 302-313.

Buden, B., Nowotny, S., Simon, Sh., Bery, A., \& Cronin, M. (2009). Cultural translation: An introduction to the problem, and Responses, In Translation Studies, 2 (2), 196-219. 
Dizdar, D. (2009). Translational transitions: "Translation proper" and translation studies in the humanities, In Translation Studies, 2 (1), 89-102.

Gaddis Rose, M. (1979). “Translation as Problem-Solving”, In Translation Review 3 (1), 20-21.

Kabakchi, V.V. (2002). The Dictionary of RUSSIA. St. Petersburg Publishing house "SOYUZ", 576 p.

Kushnina L.V., Krivoruchko A.I., \& Ushakova A.O. (2016). Cognitive mechanisms of translation, In Voprosy Kognitivnoi Lingvistiki [Issues of Cognitive Linguistics], 3, $85-95$.

Massardier-Kenney, F. (2010). Antoine Berman's way-making to translation as a creative and critical act, In Translation Studies, 3 (3), 259-271.

Munday, J. (2012). Evaluation in Translation. Routledge, 194 p.

Nord, Ch. (1991). Text Analysis in Translation. Theory, Method, and Didactic Application of a Model for Translation-Oriented Text Analysis, translated from German by C. Nord and P. Sparrow. Amsterdam/Atlanta GA, Rodopi, 250 p.

Obdržálková, V. (2016). Translation as a decision-making process: an application of the model proposed by Jiří Levý to translation into a non-mother tongue. "The Art of translation": Jiř́i Levý (1926-1967) y la otra historia de la Traductología, In Mutatis Mutandis, 9 (2), 306-327.

Prassl, F. (2010). Translators' Decision-Making Processes in Research and Knowledge Integration, In New Approaches in Translation Process Research, edited by S. Göpferich, F. Alves, and I.M. Mees, 57-81. Copenhagen: Samfundslitteratur.

Reiss, K. (1981). Type, Kind and Individuality of Text: Decision Making in Translation, In Poetics Today, 2 (4), Translation Theory and Intercultural Relations, $121-131$.

Remkhe, I.N., Nefyodova, L.A. (2016). Matrix translation model: a new perspective for mapping the process of translation, In Voprosy Kognitivnoy Lingvistiki [Issues of Cognitive Linguistics], 1, 79-90.

Steinbeck, J. (1996). The Winter of Our Discontent. Penguin Books, 276 p.

Vlahov, S., Florin, S. (1986). Neperovodimoe v perevode [Untraslatable in translation]. Moscow, Vysshaia shkola, 416 p.

Wilss, W. (1994). A Framework for Decision-Making in Translation, In Target, $6(2), 131-150$. 


\title{
Культурные, коммуникативные факторы и релевантность как основа принятия решений при переводе
}

\author{
О.В. Петрова \\ Нижегородский государственный лингвистический \\ университет им. Н.А. Добролюбова \\ Россия, 603155, Нижний Новгород, ул. Минина, 31 а
}

\begin{abstract}
Цель и задачи статьи: выявить роль осознания переводчиком культурных различий носителей исходного и переводящего языков, понимание им всех параметров коммуникативной ситуации создания текстов на ИЯ и ПЯ и способности оценить степень релевантности информации в принятии переводческих решений.

Анализ возможных переводческих решений основан на понимании перевода как творческого процесса межъязыкового и межкультурного посредничества, требующего от переводчика способности оченивать такие неформализуемые параметры коммуникации, как фоновые знания, интенция говорящего, релевантность информации.

Главное отличие переводчика-человека от переводящей машины и главное преимущество первых перед вторыми заключается в способности человека принимать непрограммируемые решения. В отличие от машины человек может оченивать релевантность информации, соотносить слова с контекстом, а не только с предметной областью, выявлять импликации и аллюзии, распознавать в тексте места, способные привести к межкультурному диссонансу. Успешность принятия контекстуально и культурно обусловленных решений зависит от наличия у переводчика профессионального переводческого мышления, развитие которого должно стать основной задачей при подготовке профессиональных переводчиков.
\end{abstract}

Ключевые слова: релевантность, контекст, осознание культурных различий, выбор, решение, переводческое мышление.

Научная специальность: 24.00.00 - культурология. 